\title{
Sistem Pakar Penentuan Penyakit Polip Hidung dengan Rinosinusitis Menggunakan Naïve Bayes Berbasis Android
}

\author{
Muhamad Nanda ${ }^{1}$, Ade Mubarok ${ }^{2}$ \\ 1,2 Universitas Adhirajasa Reswara Sanjaya \\ e-mail: ${ }^{1}$ muhamadnanda3@gmail.com, ${ }^{2}$ adem@ars.ac.id

\begin{tabular}{ccc}
\hline Diterima & Direvisi & Disetujui \\
$27-09-2020$ & $09-11-2020$ & $09-12-2020$ \\
\hline
\end{tabular}

\begin{abstract}
Abstrak - Polip Hidung adalah pertumbuhan sel atau jaringan abnormal secara lunak pada hidung dan Rinosinusitis merupakan suatu kondisi peradangan hidung dan sinus paranasal. Dua penyakit ini sering disalah artikan karena keduanya merupakan penyakit yang sering tumbuh di dalam hidung. Sistem pakar merupakan sistem yang mengambil pengetahuan manusia ke dalam komputer, kemudian dapat menyelesaikan masalah seperti orang yang ahli dalam bidangnya. Penerapan sistem pakar dalam bidang kedokteran dapat membantu para dokter untuk memudahkan dalam mendiagnosa penyakit. Penelitian ini dilakukan untuk merancang dan membuat sebuah aplikasi sistem pakar yang dapat mendiagnosa penyakit Polip Hidung dengan Rinosinusitis. Aplikasi sistem pakar ini menggunakan metode Naïve Bayes dengan menghitung jumlah kejadian suatu penyakit dengan menggunakan gejala-gejala yang timbul. Sistem aplikasi ini akan memberikan pertanyaan-pertanyaan tentang gejala yang dialami oleh pasien. Setelah pasien menjawab semua pertanyaan yang diberikan, hasil diagnosa akan muncul dan menampilkan penyakit mana yang diderita oleh pasien. Hasil dari penelitian ini adalah sebuah sistem pakar untuk melakukan diagnosa penentuan penyakit Polip Hidung dengan Rinosinusitis dengan memanfaatkan ilmu teknologi sebagai alat bantu untuk mendiagnosa penyakit.
\end{abstract}

Kata Kunci: naive bayes, polip hidung, rinosinusitis

Abstract - Nasal polyps are a growth of cell or an abnormal network which is soft inside the nasal cavity whereas Rhinosinusitis is a condition where there is an inflammation of nasal cavity and paranasal sinuses. These diseases often misundertood because both of the diseases usually grow inside the nasal cavity. Expert system is a system implement human's knowledge into computer and can solve problems.. Implementing the expert system into a medical field can help the doctors to diagnose diseases easily. In this research, there will be planning and building of an expert system that can diagnose diseases between Nasal Polyps and Rhinosinusitis. The expert system is using Nä̈ve Bayes method by calculating the probability of getting the disease using the symptoms that appear based on the value given. This expert system will provide questions based on the symptoms that experienced by the patients. After the patients answered all the questions given, the diagnostic result will appears the type of disease that the patient is suffering. The end result of this research is an expert system to diagnose diseases between Nasal Polyps and Rhinosinusitis by utilizing the knowledge of technology as a tool to diagnose diseases.

Keywords: naive bayes, nasal polyps, rhinosinusitis

\section{PENDAHULUAN}

Ketika user mengoprasikan komputer, sistem pakar akan mengeluarkan beberapa pertanyaan fakta untuk mendapatkan kesimpulan dan penjelasan. Untuk mengetahui bagaimana seseorang menghidap penyakit Rinosinusitis atau Polip Hidung akan sulit dikarenakan gejala-gejala dari kedua penyakit ini hampir mirip sehingga sering terjadi salah perkiraan.

Polip Hidung terbahagi dari dua jenis yang pertama Polip Hidung berukuran kecil yang biasanya tidak menimbulkan gejala, tetapi Polip Hidung berukuran besar, gejala yang timbul seperti bersinbersin, ingus keluar dan hidung tersumbat.
Rinosinusitis akan terjadi apabila aliran lendir tersumbat dari sinus ke rongga hidung. Antara gejala yang sering dialami oleh penderita Rinosinusitis seperti hidung tersumbat, demam, lendir berwarna kuning, nyeri kepala, nyeri gigi dan batuk.

Untuk menentukan antara penyakit Rinosinusitis dengan Polip Hidung Dalam penelitian ini digunakanlah metode Naïve Bayes, dimana metode ini akan menghitung kejadian suatu punyakit berdasarkan data-data yang telah diinput oleh user. Dengan metode ini, diharapkan dapat membedakan antara penyakit Polip Hidung dengan Rinosinusitis berdasarkan gejala-gejala yang dialami oleh pasien dengan akurat. 


\section{METODE PENELITIAN}

\section{Desain Penelitian}

Desain penelitian adalah suatu pegangan kepada penulis untuk melakukan penelitian secara jelas.

Langkah-langkah pembuatan sistem pakar diagnosa antara penyakit Polip Hidung dengan Rinosinusitis dengan menggunakan metode Nä̈ve Bayes dapat ditunjukkan pada gambar berikut:

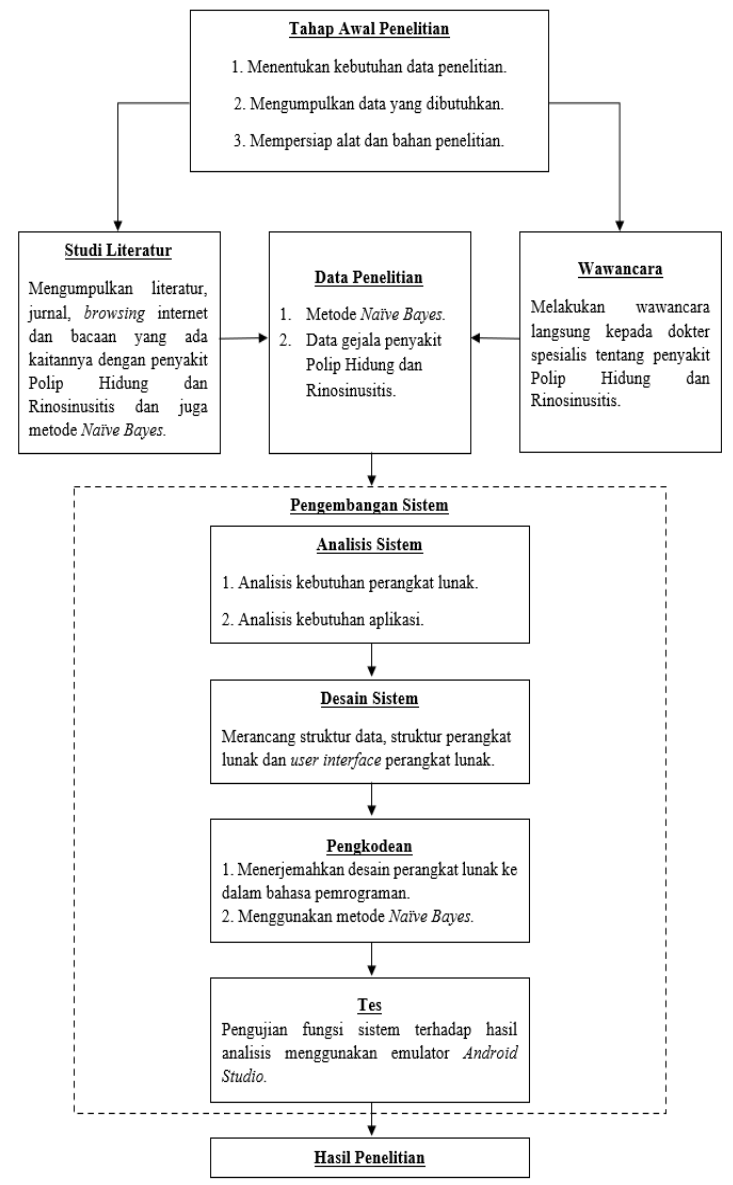

Sumber: Olahan Penulis (2020)

\section{Gambar 1. Desain Penelitian}

\section{Metode Pengumpulan Data}

Metode penelitian yang digunakandalam penyusunan skripsi ini adalah menggunakan metode Analisi Deskriptif.

Langkah ini cukup penting untuk mengumpulkan data dalam metode ilmiah, antara metode yang digunakan adalah sebagai berikut:

a. Wawancara

Wawancara ini dilakukan dengan cara mengumpulkan informasi-informasi langsung dari dokter spesialis dengan cara berkonsultasi langsung untuk mendapatkan informasi mengenai klasifikasi, gejala, kemungkinankemungkinan komplikasi dan penanganan penderita penyakit Polip Hidung dan Rinosinusitis.

b. Studi Literatur

Studi literatur dilakukan dengan menelaah secara mendalam seperti jurnal, buku dan sumber ilmiah yang didapat dari internet yang berhubungan dengan penyakit Polip Hidung dan Rinosinusitis sebagai referensi penulisan skripsi ini.

\section{Bahan dan Alat Penilitian}

a. Perangkat lunak (Software)
1) Android
2) Android Studio
3) Java
4) Android Development Tools (ADT)
5) Java Development Kit (JDK)

b. Perangkat keras (Hardware)

1) Handphone Samsung

2) Laptop Asus

\section{HASIL DAN PEMBAHASAN}

\section{Akuisisi Pengetahuan}

a. Jenis Penyakit

Berikut adalah Jenis penyakit yang akan menjadi data dalam sistem pakar ini.

Tabel 1. Jenis Penyakit

\begin{tabular}{|c|c|}
\hline Kode & Jenis Penyakit \\
\hline P1 & Polip Hidung \\
\hline P2 & Rinosinusitis \\
\hline
\end{tabular}

Sumber: Hasil Penelitian (2020)

b. Data Gejala

Penyakit yang dialami oleh user berisi pertanyaan-pertanyaan yang dialami oleh pasien untuk mendiagnosa suatu penyakit. Berikut ini tabel yang berisikan segala jenis gejala untuk mendiagnosis antara penyakit Polip Hidung dan Rinosinusitis.

Pertanyaan-pertanyaan yang akan diberikan kepada user adalah seperti berikut:

Tabel 2. Jenis Gejala untuk Mendiagnosa Antara Penyakit Polip Hidung dan Rinosinusitis

\begin{tabular}{|c|l|c|}
\hline No & \multicolumn{1}{|c|}{ Gejala } & $\begin{array}{c}\text { Kode } \\
\text { Gejala }\end{array}$ \\
\hline 1 & Bengkak pada bagian hidung? & $\mathrm{G} 1$ \\
\hline 2 & Sakit kepala berkepanjangan? & $\mathrm{G} 2$ \\
\hline 3 & $\begin{array}{l}\text { Hidung anda terasa sumbatan ingus } \\
\text { dan merasakan ingus dari hidung } \\
\text { turun ke tenggorokan? }\end{array}$ & $\mathrm{G} 3$ \\
\hline 4 & $\begin{array}{l}\text { Mengalami dengkuran yang tidak } \\
\text { biasa anda lakukan? }\end{array}$ & $\mathrm{G} 4$ \\
\hline 5 & $\begin{array}{l}\text { Mengalami sakit gigi di rahang } \\
\text { disertai dengan sakit kepala? }\end{array}$ & $\mathrm{G} 5$ \\
\hline 6 & \begin{tabular}{l} 
Mengalami demam? \\
\hline 7
\end{tabular} & Gengalami batuk berdahak? \\
\hline
\end{tabular}




\begin{tabular}{|l|l|l|}
\hline 8 & Bau mulut yang tidak biasa? & G8 \\
\hline 9 & Sekret berwarna (kuning/hijau)? & G9 \\
\hline
\end{tabular}

Sumber: Hasil Penelitian (2020)

Tabel berikut menunjukan relasi antara gejala-gejala yang di alami dan penyakitnya.

Tabel 3. Hubungan Penyakit dengan Gejala

\begin{tabular}{|c|c|}
\hline Nama Penyakit & Kode Gejala \\
\hline Polip Hidung & G1, G2, G3, G4 \\
\hline Rinosinusitis & G5, G6, G7,G8, G9 \\
\hline
\end{tabular}

Sumber: Hasil Penelitian (2020)

\section{Metode Nä̈ve Bayes}

Metode Nä̈ve Bayes dapat membuat kesimpulan dengan menggunakan multiple sources of measurement mengatasi ketidakpastian data digunakanlah formula sebagai berikut:

$$
P(H i \mid E)=\frac{P(E \mid H i) P(H i)}{\sum_{k=l}^{n} P(E \mid H k) P(H k)}
$$

Keterangan:

$P(H i \mid E)=$ Probabilitas hipotesa $H i$ terjadi jika evidence $E$ terjadi.

$P(E \mid H i)=$ Probabilitas munculnya evidence $\mathrm{E}$ jika diketahui hipotesa $H k$ benar.

$P(H i)=$ Probabilitas hipotesa Hk, tanpa memandang evidence apapun.

$n \quad=$ Jumlah hipotesa yang mungkin.

\section{Perancangan Sistem}

a. Software Arsitektur

1) Use Case Diagram

Use Case Diagram digunakan untuk mengenal pasti proses dari sistem pakar dan proses yang terjadi pada pemrograman mobile seperti yang berikut:

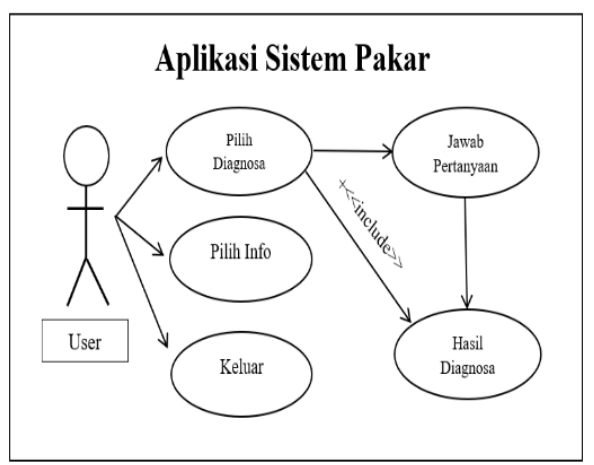

Sumber: Hasil Penelitian

Gambar 2. Use Case Diagram

2) Activity Diagram

Activity Diagram dapat menggambarkan urutan yang terjadi dalam proses secara keseluruhan seperti berikut:

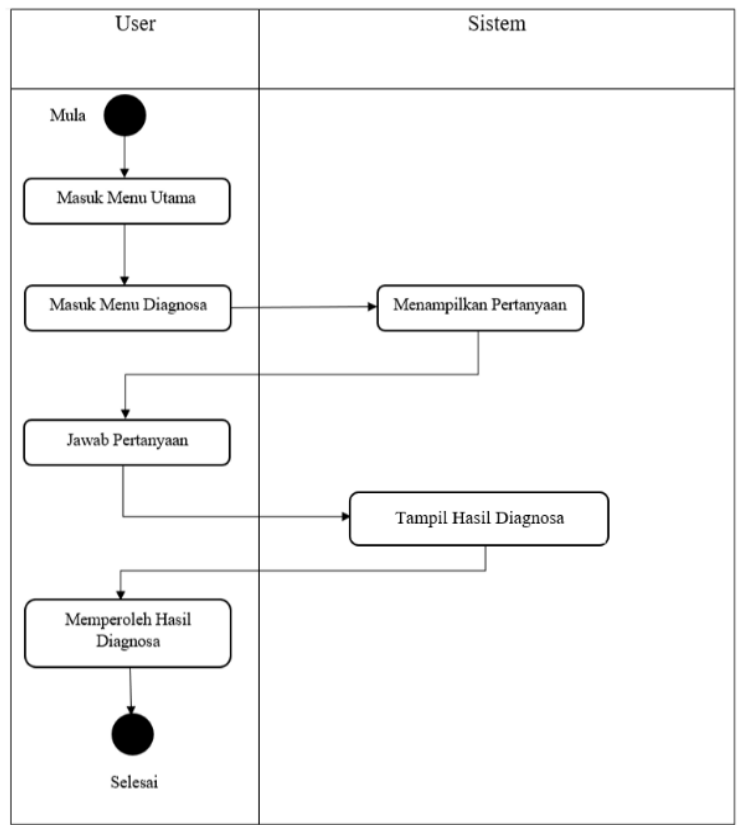

Sumber: Hasil Penelitian (2020)

Gambar 3. Activity Diagram Diagnosa

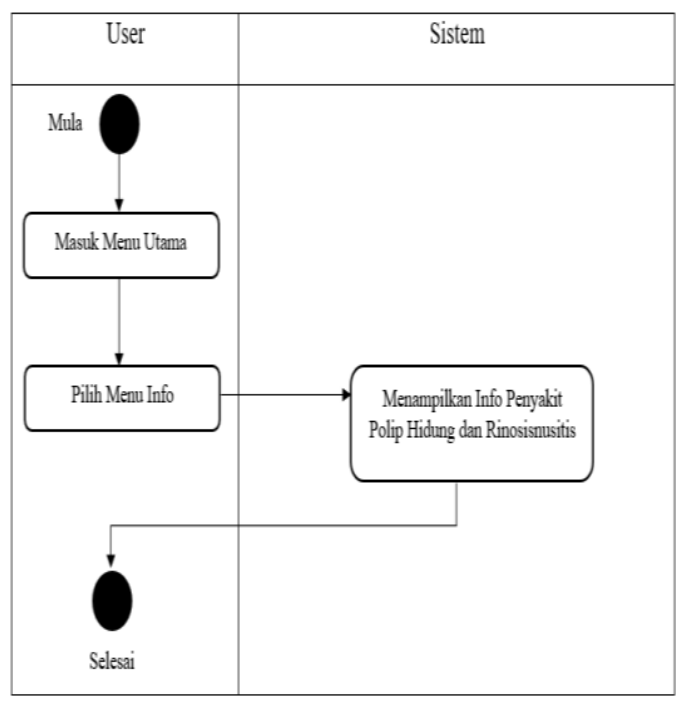

Sumber: Hasil Penelitian (2020)

Gambar 4. Activity Diagram Info 
3) Sequence Diagram

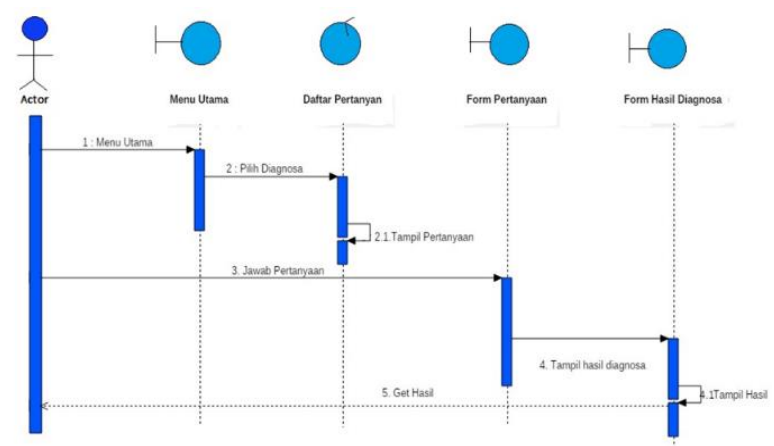

Sumber: Hasil Penelitian (2020)

Gambar 5. Sequence Diagram Diagnosa

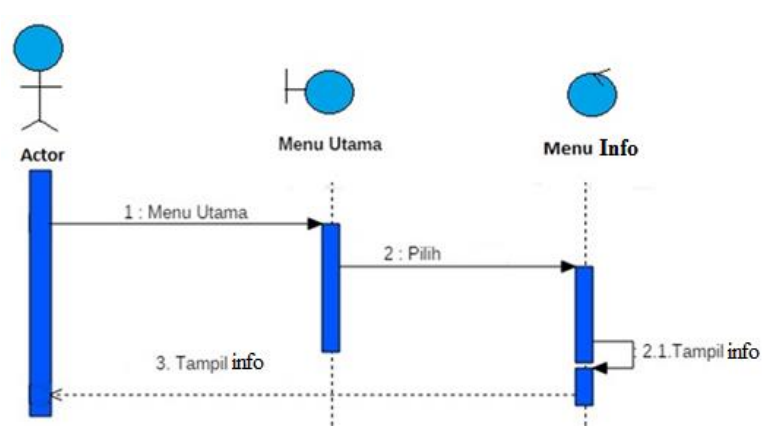

Sumber: Hasil Penelitian (2020)

Gambar 6. Sequence Diagram Info

\section{4) User Interface}

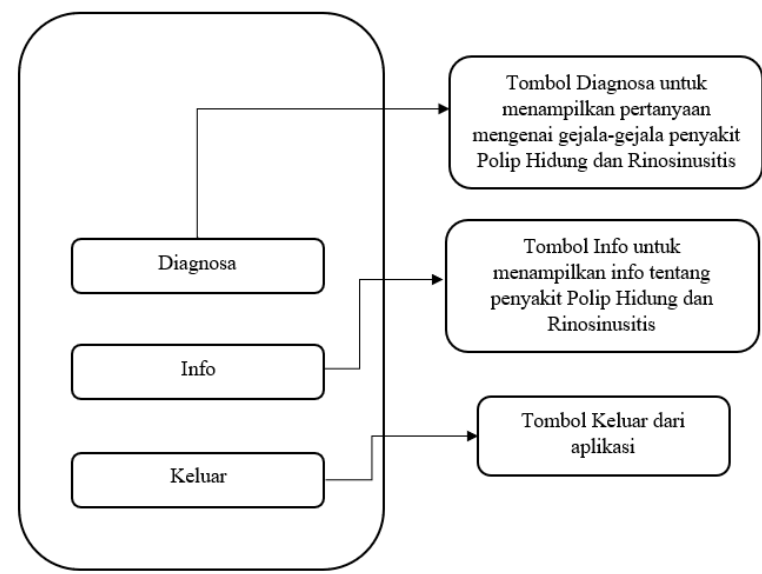

Sumber: Hasil Penelitian (2020)

Gambar 7. User Interface Home

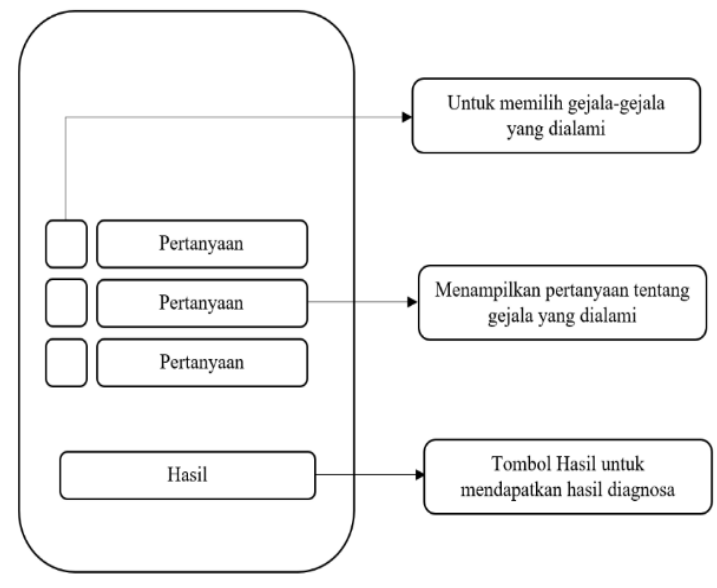

Sumber: Hasil Penelitian (2020)

Gambar 8. User Interface Halaman Pertanyaan

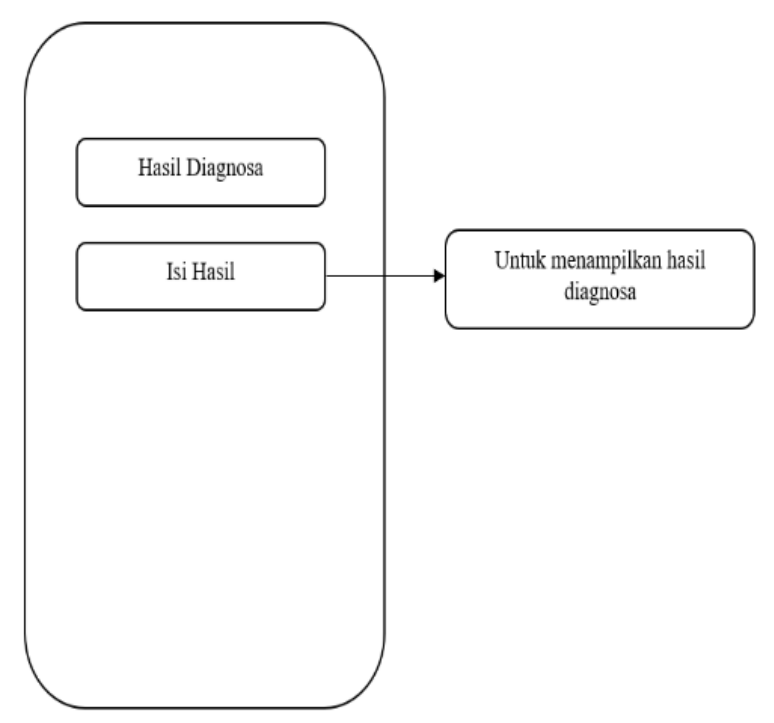

Sumber: Hasil Penelitian (2020)

Gambar 9. User Interface Halaman Hasil Diagnosa

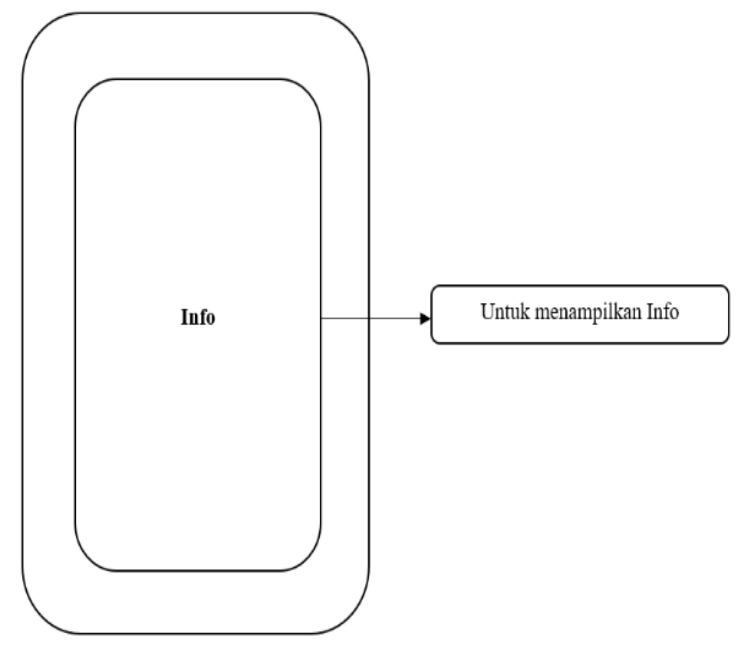

Sumber: Hasil Penelitian (2020)

Gambar 10. User Interface Info 


\section{Pengkodean}

Penulis melakukan pengkodean terhadap desain sistem yang sudah dibuat menggunakan bahasa pemrograman basic yang ditulis menggunakan aplikasi seperti Android Studio untuk sistem operasi Android.

a. Proses Perhitungan Nä̈ve Bayes

Perhitungan untuk mendiagnosa penyakit

Polip Hidung dengan Rinosinusitis serta gejala menggunakan langkah-langkah seperti berikut:

Sebagai contoh, pasien mengalami gejala:

$$
\begin{array}{ll}
\mathrm{G} 2 & =\text { sakit kepala } \\
\mathrm{G} 5 & =\text { sakit gigi di rahang } \\
\mathrm{G} 7 & =\text { batuk berdahak } \\
\mathrm{G} 9 & =\text { sekret berwarna hijau/kuning }
\end{array}
$$

Langkah-langkah perhitungan Nä̈ve Bayes adalah sebagai berikut:

1) Menentukan nilai $n_{c}$ untuk setiap class:

$n=1$

$p=1 / 2=0.5=\mathrm{P}\left(v_{j}\right)$

$m=9$

P1 (Polip Hidung):

G2 $\rightarrow n_{c}=1$

G5 $\rightarrow n_{c}=1$

G7 $\rightarrow n_{c}=1$

G9 $\rightarrow n_{c}=0$

P2 (Rinosinusitis):

$\mathrm{G} 2 \rightarrow n_{c}=1$

G5 $\rightarrow n_{c}=1$

$\mathrm{G} 7 \rightarrow n_{c}=1$

G9 $\rightarrow n_{c}=1$

2) Menghitung nilai $\mathrm{P}\left(G_{i} \mid v_{j}\right)$

Dengan menggunakan formula seperti berikut:

$$
P\left(G_{i} \mid v_{j}\right)=\frac{n_{c}+m \cdot p}{n+m}
$$

P1 (Polip Hidung):

$$
\begin{aligned}
& \mathrm{P}(\mathrm{G} 2 \mid \mathrm{P} 1)=\frac{1+(9 \times 0.5)}{9+1}=0.55 \\
& \mathrm{P}(\mathrm{G} 7 \mid \mathrm{P} 1)=\frac{1+(9 \times 0.5)}{9+1}=0.55 \\
& \mathrm{P}(\mathrm{G} 5 \mid \mathrm{P} 1)=\frac{1+(9 \times 0.5)}{9+1}=0.55 \\
& \mathrm{P}(\mathrm{G} 9 \mid \mathrm{P} 1)=\frac{0+(9 \times 0.5)}{9+1}=0.45
\end{aligned}
$$

P2 (Rinosinusitis):

$$
\begin{aligned}
& \mathrm{P}(\mathrm{G} 2 \mid \mathrm{P} 1)=\frac{1+(9 \times 0.5)}{9+1}=0.55 \\
& \mathrm{P}(\mathrm{G} 7 \mid \mathrm{P} 1)=\frac{1+(9 \times 0.5)}{9+1}=0.55 \\
& \mathrm{P}(\mathrm{G} 5 \mid \mathrm{P} 1)=\frac{1+(9 \times 0.5)}{9+1}=0.55 \\
& \mathrm{P}(\mathrm{G} 9 \mid \mathrm{P} 1)=\frac{1+(9 \times 0.5)}{9+1}=0.55
\end{aligned}
$$

3) Menghitung nilai $V_{M A P}=\mathrm{P}\left(G_{i} \mid v_{j}\right) \times \mathrm{P}\left(v_{j}\right)$ :

P1 (Polip Hidung):

$=0.5 \times 0.55 \times 0.55 \times 0.55 \times 0.45$

$=0.0374$

P2 (Rinosinusitis):

$=0.5 \times 0.55 \times 0.55 \times 0.55 \times 0.55$

$=0.0458$

4) Menentukan penyakit yang mempunyai hasil perkalian terbesar.

Didapatkan hasil nilai $V$ maksimum $\left(V_{M A P}\right)$ sebesar 0.0458 , pasien didiagnosa megidap penyakit Rinosinusitis.

\section{Tes}

Tahap ini dilakukan untuk melihat error pada aplikasi yang sudah dibuat.

\section{Implementasi}

Tahap implementasi dilakukan untuk melihat hasil setelah selesai dibuat dan bagaimana aplikasi setelah dijalankan.

a. Hasil Implemantasi Aplikasi

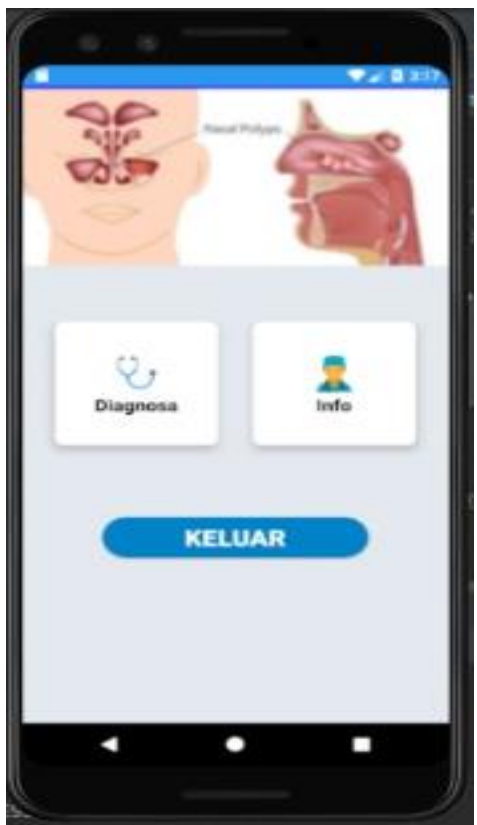

Sumber: Hasil Penelitian (2020)

Gambar 11. Tampilan Halaman Menu Utama 


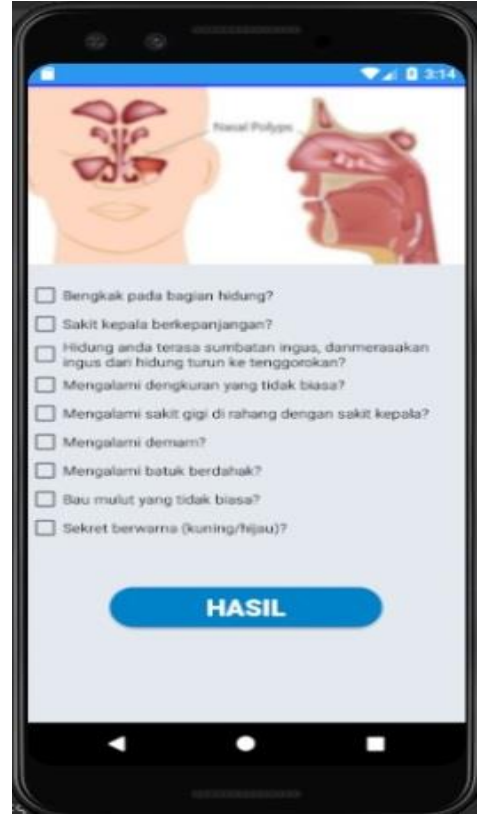

Sumber: Hasil Penelitian (2020)

Gambar 12. Tampilan Halaman Pertanyaan

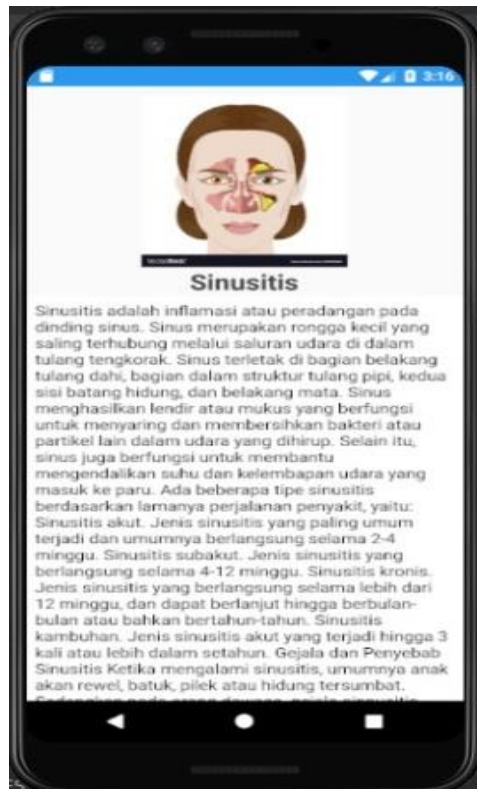

Sumber: Hasil Penelitian (2020)

Gambar 13. Tampilan Halaman Info Penyakit Rinosinusitis

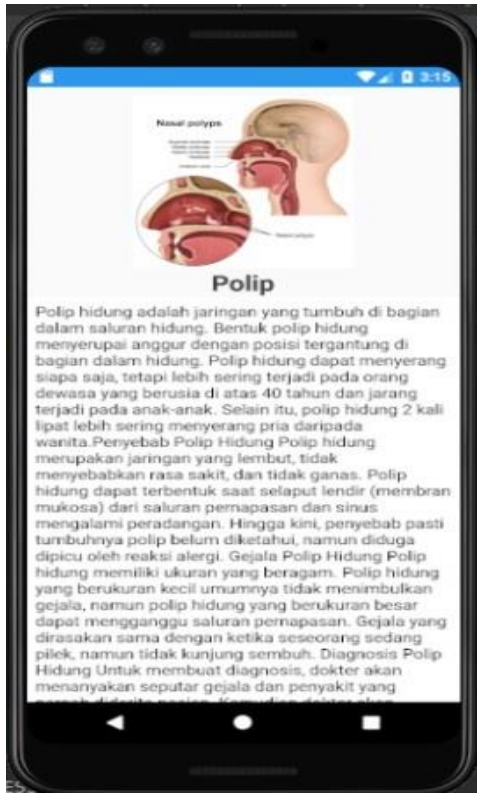

Sumber: Hasil Penelitian (2020)

Gambar 14. Tampilan Halaman Info Penyakit Polip Hidung

\section{Hasil Pengujian Aplikasi}

Metode pengujian aplikasi ini dilakukan menggunakan emulator Android Studio. Pengujian ini dilakukan untuk menguji dan melihan fungsi aplikasi berfungsi atau tidak. Berikut adalah hasil pengujian menggunakan emulator Android Studio dari aplikasi sistem pakar diagnosa Penyakit Polip Hidung dengan Rinosinusitis menggunakan Nä̈ve Bayes berbasis Android:

Tabel 4. Hasil Pengujian Aplikasi Menggunakan Emulator Android Studio

\begin{tabular}{|c|l|c|}
\hline Pengujian & \multicolumn{1}{|c|}{ Tampilan } & Hasil \\
\hline Menu Utama & $\begin{array}{l}\text { Tampilan untuk } \\
\text { halaman utama } \\
\text { aplikasi sistem } \\
\text { pakar }\end{array}$ & Sukses \\
\hline Menu Diagnosa & $\begin{array}{l}\text { Tampilan untuk } \\
\text { menjawab } \\
\text { pertanyaan tentang } \\
\text { gejala penyakit }\end{array}$ & Sukses \\
\hline Hasil Diagnosa & $\begin{array}{l}\text { Menampilkan hasil } \\
\text { diagnosa } \\
\text { berdasarkan } \\
\text { jawapan yang } \\
\text { dipilih sebelumnya }\end{array}$ & Sukses \\
\hline Menu Info & $\begin{array}{l}\text { Tampilan untuk } \\
\text { menampilkan } \\
\text { penjelasan tentang } \\
\text { penyakit Polip } \\
\text { Hidung dan } \\
\text { Rinosinusitis }\end{array}$ & Sukses \\
\hline
\end{tabular}

Sumber: Hasil Penelitian (2020) 


\section{Pembahasan}

a. Prosedur Kerja Sistem

Sistem pakar yang dibuat memiliki beberapa prosedur kerja, dimana setiap tampilan memiliki prosedur kerja tersendiri. Berikut ini akan dijelaskan prosedur kerja sistem pakar diagnosa:

1) Menu Halaman Utama

Pada saat tampilan menu halaman utama, user memilih button untuk masuk ke dalam menu Diagnosa.

2) Tampilan Halaman Diagnosa User diharuskan menjawab pertanyaan tentang gejala-gejala yang ditampilkan pada aplikasi, setelah itu sistem akan mengeluarkan hasil diagnosa.

3) Tampilan Info

Proses kerja tampilan info ini adalah hanya untuk menampilkan penjelasan tentang penyakit Polip Hidung dan Rinosinusitis.

\section{KESIMPULAN}

Hasil penelitian ini, implementasi yang dilakukan pada sistem pakar diagnosa penentuan penyakit Polip Hidung dengan Rinosinusitis menggunakan metode Nä̈ve Bayes berbasis Android, maka dapat disimpulkan sebagai berikut:

1. Metode Nä̈ve Bayes dapat mengklasifikasikan gejala-gejala untuk penyakit Polip Hidung dan Rinosinusitis berdasarkan input data yang diisi oleh user.

2. Metode Nä̈ve Bayes dapat mendiagnosa penyakit Polip Hidung dengan Rinosinusitis dengan baik,

Setelah mempelajari tentang penyakit Polip Hidung dengan Rinosinusitis ini kiranya penulis dapat memanfaatkan semaksimal mungkin materi ini sehingga penulis dapat mengerti dan memahami tentang bedanya penyakit antara Polip Hidung dengan Rinosinusitis.

\section{REFERENSI}

Arianti, K. 2020. Hidung Sering Tersumbat, Benarkah Merupakan Gejala Awal Penyakit Polip Hidung? Diambil dari https://www.gooddoctor.co.id/tipskesehatan/penyakit/penyakit-polip-hidung/.
Arif, Firman. 2019. Analisis dan Perancangan Sistem Informasi. Pasuruan: Penerbit Qiara Media.

B. Herawan Hayadi. 2018. Sistem Pakar. Yogyakarta: Deepublish Publisher.

El Hakim, Nurul Hidayat dan Ratih Kartika Dewi. 2018. Sistem Pakar Diagnosis Penyakit Telinga Hidung Tenggorokan Menggunakan Metode Nä̈ve Bayes Berbasis Android. Diambil dari: http://j-ptiik.ub.ac.id/index.php/jptiik/article/view/1227/.

Fanny, N.A. Hasibuan dan E. Buulolo. Q. 2017. Perancangan Sistem Pakar Diagnosa Penyakit Asidosis Tubulus Renalis Menggunakan Metode Certainty Factor Dengan Penulusuran Forward Chaining. Diambil dari: https://ejurnal.stmik-

budidarma.ac.id/index.php/mib/article/view/31 6/267/.

Fazry, Lhuqita. 2017. Membuat Aplikasi Android Untuk Pemula. Diambil dari: https://www.scribd.com/document/357903498 /Membuat-Aplikasi-Android-DenganAndroid-Studio/.

Hamsyah, Resa Septrian. 2018. Rancang Bangun Aplikasi Go-ban untuk Mencari dan Memanggil Teknisi Tambal Ban Menggunakan Google Maps API. Diambil dari: https://core.ac.uk/download/pdf/151573741.pd f/.

Husni, Teuku. 2015. Diagnosis dan Penanganan Rinosinusitis. Diambil dari: http://conference.unsyiah.ac.id/TIFK/1/paper/v iewFile/783/78/.

Jusnita. 2018. Desain Penelitian Kualitatif dan Kuantitatif: Contoh Lengkap. Diambil dari: http://sosiologis.com/desain-penelitian/.

Kesuma, Eko Hadi. 2019. Tutorial Lengkap Belajar Android. Diambil dari: https://www.scribd.com/document/425590543 /Tutorial-Lengkap-Belajar-Android/.

Pratiwi, Heny. 2019. Buku Ajar: Sistem Pakar. Kuningan: Goresan Pena. 